\title{
Analisis Faktor yang Mempengaruhi Kredibilitas Kinerja Perusahaan
}

\author{
Zaini Danu Brata ${ }^{1}$ \\ Fakultas Ekonomi dan Bisnis \\ Universitas Udayana, Indonesia. \\ Email: zainidanubrata@yahoo.com
}

\author{
Maria M. Ratna Sari ${ }^{2}$ \\ Fakultas Ekonomi dan Bisnis \\ Universitas Udayana, Indonesia.
}

\begin{abstract}
ABSTRAK
Tujuan dari penelitian ini adalah untuk mengetahui Pengaruh Penerapan Good Corporate Governance, Struktur Kepemilikan, dan Ukuran Perusahaan terhadap Kinerja Perusahaan. Beberapa faktor Penelitian ini bertujuan untuk mengetahui pengaruh Good Corporate Governance (CGPI) terhadap Kinerja Perusahaan yang terdaftar di BEI periode 2013-2017. Populasi penelitian adalah perusahaan yang terdaftar di bursa efek Indonesia sekaligus mengikuti pemeringkatan Corporate Governance Perception Index dengan pemilihan sampel melalui metode purposive sampling. Terdapat 55 perusahaan yang memenuhi kriteria sebagai sampel penelitian. Hasil penelitian menunjukkan bahwa Good Corporate Governance berpengaruh positif dsn signifikan terhadap Kinerja perusahaan, Kepemilikan Manajerial berpengaruh positif dan signifikan terhadap Kinerja perusahaan, Kepemilikan Institusional tidak berpengaruh positif dan signifikan terhadap Kinerja Perusahaan, Ukuran Perusahaan berpengaruh positif dan signifikan terhadap Kinerja Keuangan.
\end{abstract}

Kata Kunci: Good corporate governance, kepemilikan manajerial, kepemilikan institusional, ukuran perusahaan, kinerja perusahaan.

\section{Analysis of Factors Affecting the Credibility of Company Performance}

\begin{abstract}
The purpose of this study is to determine the effect of the application of Good Corporate Governance, Ownership Structure, and Company Size on Company Performance. Several factors This study aims to determine the effect of Good Corporate Governance (CGPI) on the Performance of Companies listed on the IDX for the period 2013-2017. The research population is a company that is listed on the Indonesian stock exchange and at the same time follows the ranking of the Corporate Governance Perception Index with sample selection through a purposive sampling method. There are 55 companies that meet the criteria as research samples. The results show that Good Corporate Governance has a significant positive effect on company performance, Managerial Ownership has a positive and significant effect on company performance, Institutional Ownership does not have a positive and significant effect on Company Performance, Company Size positive and significant effect on Financial Performance.
\end{abstract}

Keywords: Good corporate governance, ownership structure, company size, company performance.

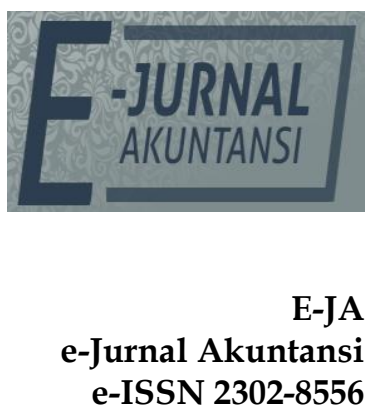

Denpasar, Vol. 28 No. 3

September 2019 Hal. 1801-1818

Artikel masuk: 29 April 2019

Tanggal diterima: 08 Juli 2019 


\section{PENDAHULUAN}

Pertumbuhan dunia usaha saat ini semakin pesat, sehingga diikuti dengan pesatnya persaingan menyebabkan setiap perusahaan harus memiliki tujuan yang jelas agar perusahaan dapat beroperasi. Umumnya tujuan perusahaan adalah memaksimalkan laba, keberhasilan perusahaan dalam meningkatkan kesejahteraan dan kemakmuran para pemegang saham menjadi salah satu faktor penunjang bagi perusahaan dalam meningkatkan kinerja perusahaannya. Kinerja perusahaan yang baik dimata para investor menjadi pertimbangan penting bagi perusahaan. Meningkatnya penanaman modal saham yang diberikan oleh investor bagi perusahaan tidak hanya bertujuan untuk memperoleh keuntungan, namun juga dapat mempercepat laju pertumbuhan perusahaan sehingga dapat bersaing lebih kompetitif baik dalam pasar domestik maupun pasar internasional.

Menurut Arora \& Sharma (2016) Kinerja perusahaan dianggap baik jika adanya keyakinan investor terhadap suatu perusahaan bahwa dana yang mereka investasikan dalam kondisi yang aman dan diharapkan akan memberikan return atas dana yang telah mereka investasikan. Para investor akan menghindari perusahaan yang memiliki kinerja yang buruk dan lebih memilih menginvestasikan dananya pada perusahaan yang memiliki kinerja yang baik yang dapat menjamin kemakmuran serta melindungi hak dan kepentingan para pemegang saham. Kondisi ini yang menjadi acuan perusahaan terutama perusahaan yang telah go public agar dapat menarik investor-investor untuk menanamkan modalnya ke perusahaan-perusahaan mereka.

Kinerja dapat diartikan sebagai prestasi yang dicapai perusahaan dalam suatu periode tertentu yang mencerminkan tingkat kesehatan perusahaan tersebut (Rubianti, 2013). Tercapainya suatu kinerja yang baik dapat dibuktikan dari bagaimana perusahaan dapat menghasilkan keuntungan yang sebanyakbanyaknya. Hal ini menjadi daya tarik utama bagi investor, bahwa perusahaan tersebut dapat memberikan keuntungan baginya dan dapat mengurangi risiko atas tidak kembalinya dana yang ditanamkan. Namun, pencapaian kinerja yang baik bukanlah hal yang mudah bagi perusahaan. Banyak penelitian yang dilakukan oleh peneliti untuk menentukan faktor-faktor yang dapat mempengaruhi kinerja suatu perusahaan salah satunya Good Corporate Governance(Wandroski Peris dkk., 2017).

Good Corporate Governance (GCG) menjadi isu penting pada saat terjadinya kasus manipulasi dan kebangkruntan besar-besaran yang terjadi di perusahaanperusahaan besar di Amerika Serikat (AS). Kasus ini terjadi akibat buruknya sistem dari tata kelola perusahaan. Menurut Nurdin, 2016 mengemukakan bahwa salah satu contoh manipulasi yang menimpa Enron disebabkan oleh kegagalan Dewan Direksi untuk melindungi kepentingan para pemegang saham Enron, atau sering disebut sebagai fiduciary failure. Dewan direksi Enron telah menyalah gunakan kepercayaan para pemegang saham.

Tidak hanya di Amerika Serikat, di Indonesia juga timbul krisis ekonomi pada perusahaan besar, seperti PT Lapindo Brantas. PT Lapindo Brantas, Inc adalah suatu perusahaan eksplorasi dan produksi migas di Indonesia yang beroperasi melalui skema Kontraktor Kontrak Kerja Sama (KKKS) di blok Brantas, Jawa Timur. Mengalami masalah yaitu adanya kesalahan dalam 
pengeboran gas alam. Penyebab adanya semburan lumpur panas tersebut adalah PT Lapindo Brantas dianggap kurang teliti dalam melakukan pengeboran sumur dan terlalu menyepelekan baik kinerja maupun dampak yang mungkin dapat diterima atas pengeboran yang PT Lapindo Brantas. Akibat dari kelalaian Kinerja dari PT. Lapindo Brantas menyebabkan kerugian bagi pihak ekstern perusahaan yaitu tutupnya tidak kurang dari 10 pabrik, merendam lebih dari 100 hektar lahan produktif dan pemukiman penduduk yang pada akhirnya memaksa para penduduk setempat untuk mengungsi ke tempat yang lebih aman agar tidak terendam lumpur panas tersebut.

Kerugian intern yang dialami perusahaan adalah meruginya pihak pemegang saham serta memburuknya citra perusahaan dimata investor serta masyarakat umum bahkan PT. Lapindo Brantas tidak mampu lagi meneruskan kegiatan usahanya yang disebabkan oleh bad corporate governance. Hal ini disebabkan Karena dewan direksi dan komisaris tidak menjalankan fungsifungsi utamanya. Fungsi-Fungsi utama yang dilanggar komisaris adalah kurangnya memonitor penerapan dan kinerja perusahaan, serta tidak adanya kebijakan mengenai risiko. Selain itu, komisaris tidak mengawasi kebijakan direksi dalam menjalankan perseroan. Kemudian, dewan komisaris tidak memonitor dan mengelola potensi benturan kepentingan dari manajemen dan tidak mengawasi proses keterbukaan atau transparansi pada suatu masalah.

Tata kelola perusahaan yang baik sebagai suatu sistem yang mengatur hubungan peran dewan komisaris, peran direksi, pemegang saham, dan pemangku kepentingan lainnya. Tata kelola perusahaan yang baik juga disebut sebagai suatu proses yang transparan atas penentuan tujuan perusahaan, pencapaiannya dan penilaian kinerjanya. Mengatur keselarasan antara dewan komisaris, dewan direksi, pemegang saham dan pemangku kepentingan lainnya, yaitu karyawan, pemasok, pelanggan, bank dan kreditor lain, regulator, lingkungan, serta masyarakat luas sangat penting dalam penerapan tata kelola perusahaan yang baik (Nurdin, 2016).

Hubungan antara principal dan agent diwujudkan dalam hubungan antara pemegang saham dan manajer. Pemegang saham berperan sebagai principal sementara manajer berperan sebagai agent. Manajer perusahaan diharapkan mampu memenuhi keinginan pemilik atau pemegang saham perusahaan dalam meningkatkan keuntungan perusahaan dan meningkatkan kinerja perusahaan sehingga nilai suatu perusahaan dapat meningkat di mata masyarakat. Manajer diharapkan mampu berusaha memaksimalkan harga saham perusahaan dan dapat berkomunikasi secara efektif dengan pemegang saham. Menurut Bringham \& Huston (2013) mengemukakan bahwa sering kali tujuan pribadi manajer mungkin bertentangan dengan memaksimalisasi kekayaan pemegang saham. Khususnya, manajer mungkin lebih tertarik untuk memaksimalkan kekayaan mereka sendiri daripada kekayaan pemegang saham sehingga mereka mendapat gaji lebih. Tidak samanya tujuan antara manajer dan pemegang saham inilah yang dapat menyebabkan konflik agensi (agency conflict).

Adanya kepemilikan manajerial dan kepemilikan institusional dalam suatu perusahaan diharapkan dapat meningkatkan kinerja perusahaan karena manajer akan hati-hati dalam mengambil keputusan operasi dan strategi bagi perusahaan dan dapat melaporkan informasi terkait keadaan perusahaan yang 
sebenarnya secara transparan agar tidak terjadi asimetri informasi antara agen dan pemilik (pemegang saham) perusahaan. Beberapa studi menyatakan peran dari struktur kepemilikan pada Kinerja perusahaan. Seperti yang diungkapkan oleh Michael C \& Meckling (1976) bahwa agency conflict muncul akibat adanya pemisahan antara kepemilikan dan pengendalian perusahaan. Kepemilikan manajerial dan kepemilikan institusional adalah dua mekanisme Good corporate governance utama yang membantu mengendalikan masalah keagenan. Restu (2018)dan Krenz (2016)menyimpulkan bahwa kepemilikan manajerial yang tinggi dapat digunakan untuk membantu mengurangi masalah keagenan dan dengan adanya kepemilikan oleh institusional seperti perusahaan asuransi, bank, perusahaan-perusahaan investasi dan kepemilikan oleh institusi akan mendorong peningkatan pengawasan yang lebih optimal. Mekanisme monitoring tersebut akan menjamin peningkatan kemakmuran pemegang saham. Signifikasi institusional ownership sebagai agen pengawas ditekankan melalui investasi mereka yang cukup besar dalam pasar modal(Omoregie dkk., 2019). Apabila institusional merasa tidak puas atas kinerja manajerial, maka mereka akan menjual sahamnya ke pasar.

Hal tersebut didasarkan pada logika bahwa peningkatan proporsi saham yang dimiliki manajer akan menurunkan kecenderungan manajer untuk melakukan tindakan mengkonsumsi keuntungan yang berlebihan, dengan demikian akan menyatukan kepentingan.Selain penerapan Good Corporate Governance dan struktur kepemilikan, perusahaan perlu mempertimbangkan karakteristik lain yang mempengaruhi kinerja perusahaan. Ukuran perusahaan merupakan salah satu karakteristik yang perlu diperhatikan. Karena besar kecilnya suatu perusahaan dilihat dari besarnya aset yang dimiliki oleh perusahaan tersebut. Perusahaan yang lebih besar dapat memberikan informasi yang lebih baik bagi investor dalam kepentingan investasi, karena perusahaan yang besar akan mendapatkan perhatian lebih oleh masyarakat sehingga dalam melakukan pelaporan perusahaan akan lebih hati-hati dalam melaporkan kinerja perusahaan yang tercermin dari laporan keuangan.

Terdapat perbedaan hasil penelitiandari beberapa penelitian terdahulu mengenai pengaruh GCG, kepemilikan manajerial, kepemilikan institusional, dan ukuran perusahaan terhadap kinerja perusahaan. Menurut penelitian yang dilakukan oleh Veno (2015) menunjukan bahwa GCG berpengaruh secara signifikan terhadap kinerja perusahaan. Berbeda dengan hasil penelitian yang dilkukan oleh Ayu (2014) yang menemukan bukti bahwa GCG dan ukuran perusahaan tidak berpengaruh signifikan terhadap kinerja perusahaan. Sedangkan, menurut penelitian yang dilakukan oleh Reza (2014) menunjukan bahwa kepemilikan manajerial tidak berpengaruh signifikan terhadap Kinerja perusahaan. Namun, Claudia (2017) menunjukan bahwa kepemilikan Manajerial berpengaruh signifikan terhadap Kinerja perusahaan. Menurut Yus (2017) menunjukan bahwa ukuran perusahaan tidak berpengaruh terhadap Kinerja perusahaan. Namun menurut Hantono (2016) menunjukan bahwa ukuran perusahaan berpengarug signifikan terhadap Kinerja perusahaan.

Good corporate governance adalah sebuah sistem yang mengatur dan mengendalikan perusahaan untuk menciptakan nilai tambah bagi perusahaan dan pemangku kepentingan. GCG timbul karena kepentingan perusahaan untuk 
memastikan kepada pihak penyandang dana (principal/investor) bahwa dana yang ditanamkan digunakan secara tepat. Selain itu dengan adanya Teori agensi menimbulkan keinginan pihak manajemen (agent) untuk meningkatkan laba. Karena sebagai pengelola perusahaan, manajer (agent) bertanggung jawab untuk meningkatkan kinerja perusahaan dan memberikan keuntungan kepada para pemilik perusahaan (principal) secara optimal, kemudian sebagai imbalannya pihak manajer akan memperoleh bonus dari prinsipal sesuai dengan perjanjian yang telah dibuat (Rejeb dan Frioui, 2014).

Kinerja perusahaan ditentukan sejauh mana keseriusannya dalam menerapkan GCG. Perusahaan yang terdaftar dalam skor pemeringkatan GCG yang dilakukan oleh IICG telah menerapkan GCG dengan baik dan secara langsung menaikkan nilai sahamnya. Semakin tinggi penerapan GCG yang diukur dengan Corporate Governance Perception Indeks (CGPI) semakin tinggi pula tingkat ketaatan perusahaan dan menghasilkan kinerja perusahaan yang baik (Adebayo dkk., 2014). Secara teoretis praktik GCG dapat meningkatkan kinerja perusahaan, mengurangi risiko yang mungkin dilakukan oleh dewan dengan keputusan yang menguntungkan sendiri dan umumnya GCG dapat meningkatkan kepercayaan investor untuk menanamkan modalnya yang berdampak terhadap kinerjanya (Jacobo Hernandez, 2017).

Berbagai penelitian telah dilakukan untuk membuktikan pengaruh GCG terhadap kinerja/nilai perusahaan. Penelitian yang dilakukan oleh Aggrawal (2013), Michelbelger (2017), Andriana (2017) yang menemukan bahwa GCG memiliki hubungan positif dengan nilai atau kinerja perusahaan. (Suntraruk, 2013) menemukan hubungan positif antara indeks GCG dengan kinerja perusahaan jangka panjang. Andri (2015), Nurdiniah (2017) yang menguji penerapan GCG dan kinerja perusahaan, menyimpulkan bahwa GCG berpengaruh terhadap kinerja perusahaan. Menurut Meidona (2018), Mittal Shrivastav (2015) menemukan bahwa GCG berpengaruh positif terhadap Kinerja. Adanya Prinsip GCG dalam suatu perusahaaan diharapkan perusahaan akan memiliki nilai tambah bagi para investor, pemangku kepentingan serta mendorong Kinerja agar sesuai dengan prinsip GCG.

Berdasarkan uraian di atas, maka hipotesis dalam penelitian ini di rumuskan sebagai berikut :

$\mathrm{H}_{1}$ : Good Corporate Governance berpengaruh positif terhadap Kinerja Perusahaan.

Kepemilikan manajerial merupakan kondisi dimana manajer memiliki saham perusahaan tersebut sehingga dia memiliki rangkap jabatan, selain sebagai pengelola perusahaan manajer juga sebagai pemilik saham di perusahaan tersebut. Kepemilikan manajerial dalam suatu perusahaan akan mendorong manajemen untuk meningkatkan kinerja perusahaan. Hal tersebut dikarenakan kepentingan para manajer yang juga memiliki perusahaan. Kinerja manjerial merupakan suatu persentase suara yang berkaitan dengan saham dan option yang dimiliki oleh manajer dan direksi perusahaan. Guna mengurangi konflik kepentingan antara agent dan principal dapat dilakukan dengan meningkatkan kepemilikan manjerial dalam suatu perusahaan. 
Semakin meningkat proporsi kepemilikan saham manajerial maka manjemen akan cenderung berusaha lebih giat untuk kepentingan saham yang tidak lain adalah dirinya sendiri. Adanya peningkatan kepemilikan manajerial dalam perusahaan akan menyelaraskan kepentingan manajer dengan pemegang saham, sehingga manajer akan merasakan secara langsung manfaat dari keputusan yang diambil dan juga ikut menanggung kerugian sebagai sebuah konsekuensi dari kesalahan dalam pengambilan keputusan. Jika suatu perusahaan tidak menerapkan kepemilikan manajerial, maka manajer perusahaan akan mementingkan kepentingannya karena dia merasa bukan sebagai pemegang saham (Michael C dan Meckling, 1976).

Level kepemilikan manajerial lebih tinggi maka dapat digunakan untuk mengurangki masalah keagenan karena dengan peningakatan proporsi saham yang dimiliki manajer akan menurunkan kecenderungan manajer untuk melakukan tindakan konsumsi yang mementingkan dirinya sendiri dengan demikian akan menyatukan kepemtingan antara manajer dan pemegang saham (Anita, 2016). Menurut O'Callaghan (2018) menyatakan bahwa kepemilikan manajerial adalah pemegang saham dari pihak manajemen (dewan direksi dan dewan komisaris) yang secara aktif ikut dalam pengambilan keputusan, dengan ini maka yang dimaksud dengan kepemilikan manajerial yaitu direktur dan juga komisaris dari suatu perusahaan. Dengan demikian dengan adanya kepemilikan manajerial dalam suatu perusahaan maka manajer akan terpacu untuk memajukan perusahaanya agar dapat menguntungkan bagi dirinya sendiri dan pemegang saham yang menanamkan modalnya dalan perusahaan.

Berdasarkan uraian di atas, maka hipotesis dalam penelitianini di rumuskan sebagai berikut :

$\mathrm{H}_{2}$ : Kepemilikan manajerial berpengaruh positif terhadap kinerja perusahaan.

Kepemilikan institusional merupakan kondisi dimana institusi memiliki saham dalam suatu perusahaan. Kepemilikan institusional dapat berupa saham yang dimiliki oleh institusi atau lembaga seperti perusahaan asuransi, bank, perusahaan investasi, dan kepemilikan institusi lain. Adanya konflik yang terjadi akibat dari pemisahan kepemilikan yang dapat berdampak pada pengendalian dan pelaksanaan pengelolaan perusahaan yang dapat menyebabkan para manajer bertindak tidak sesuai dengan keinginan pemilik perusahaan, dapat diminimalisir dengan adanya pengawasan terhadap perusahaan tidak hanya terbatas pada yang dilakukan oleh pihak dalam perusahaan, tetapi juga dapat dilakukan dari pihak eksternal perusahaan yaitu dengan mengaktifkan pengawasan melalui investor-investor institusional. Kepemilikan institusional merupakan kepemilikan saham oleh pemerintah, institusi keuangan, institusi berbadan hukum, institusi luar negeri, dana perwakilan serta institusi lainnya pada akhir tahun (Tytus, 2016). Kepemilikan oleh investor institusional dalam perusahaan akan mendorong pengawasan yang lebih optimal terhadap kinerja manajemen, yang dapat berakibat juga pada peningkatan kinerja perusahaan.

Kepemilikan Institusional umumnya dapat bertindak sebagai pihak yang memonitor perusahaan. Investor institusional akan memberikan pemantauan secara profesional terhadap perkembangan investasi yang telah ditanamkan pada perusahaan dan memiliki tingkat pengendalian yang tinggi terhadap 
tindakan yang dilakukan oleh manajemen (Zarkasyi dkk, 2019). Hal tersebut dilakukan untuk memperkecil kecurangan yang dilakukan oleh manajemen, sehingga dapat menyelaraskan kepentingan manajemen dan para stakeholder lainnya untuk meningkatkan kinerja perusahaan.

Beberapa penelitian telah membuktikan bahwa peningkatan kepemilikan institusional dalam perusahaan dapat mengoptimalkan nilai perusahaan. Semakin besar kepemilikan institusional maka semakin efisien pemanfaatan aktiva perusahaan dan diharapkan juga dapat bertindak sebagai pencegahan terhadap pemborosan yang dilakukan oleh manajemen. Hasil Penelitian Natali (2017), Aprianingsih (2016), Purwati (2018) bahwa semakin besar kepemilikan oleh institusi keuangan maka semakin besar pula kekuatan suara dan dorongan untuk mengoptimalkan nilai perusahaan. Selain itu, semakin tinggi kepemilikan institusional maka akan mengurangi perilaku opportunisme manajer yang dapat mengurangi agency cost yang diharapkan akan meningkatkan nilai perusahaan. Hal tersebut dapat didasarkan pada logika bahwa semakin besar kepemilikan oleh institusi dalam perusahaan, maka akan semakin besar kekuatan suara dan dorongan institusi untuk mengawasi manajemen, sehingga diharapkan akan memberikan dorongan yang lebih besar untuk mengoptimalkan nilai perusahaan serta adanya peningkatan kinerja perusahaan. Tingginya kepemilikan oleh sebuah institusi akan meningkatkan pengawasan terhadap perusahaan yang dapat meminimalisir masalah keagenan.

Berdasarkan uraian di atas, maka hipotesis dalam penelitian ini di rumuskan sebagai berikut :

$\mathrm{H}_{3}$ : Kepemilikan institusional berpengaruh positif terhadap kinerja perusahaa.

Ukuran perusahaan merupakan ukuran besar kecilnya perusahaan. Ukuran perusahaan dilihat dari total aset yang dimiliki perusahaan. Apabila suatu perusahaan memiliki total aset yang besar bisa disimpulkan bahwa perusahaan tersebut adalah perusahaan besar. Perusahaan besar biasanya dipandang sebagai perusahaan yang relatif stabil dan mampu menghasilkan laba yang cukup tinggi. Pihak luar maupun investor akan melihat perusahaan besar ini sebagai perusahaan yang baik untuk menanamkan dananya sehingga memiliki nama atau reputasi yang baik di mata pihak eksternal. Melalui reputasi yang baik ini, manajer akan semakin berhati-hati dalam melakukan pengelolaan perusahaan. Manipulasi dan tindak kecurangan dalam perusahaan pun akan berkurang.

Ukuran perusahaan merupakan hal yang penting dalam proses pelaporan keuangan. Ukuran perusahaan dalam penelitian ini diukur dengan melihat seberapa besar aset yang dimiliki oleh sebuah perusahaan. Aset yang dimiliki perusahaan ini menggambarkan hak dan kewajiban serta permodalan perusahaan. Ukuran perusahaan akan berpengaruh terhadap perkembangan perusahaan. Menurut Rizal (2016) menyatakan bahwa perusahaan besar pada dasarnya memiliki kekuatan finansial yang lebih besar dalam menunjang kinerja, tetapi disisi lain, perusahaan dihadapkan pada masalah keagenan yang lebih besar. Hantono (2016), Ulfa Syahida (2016), Yuli Sawitri (2017) dalam penelitiannya menemukan bukti bahwa ukuran perusahaan berpengaruh positif signifikan terhadap kinerja perusahaan. Perusahaan dengan aset besar biasanya 
akan mendapatkan perhatian lebih dari masyarakat. Hal ini akan menyebabkan perusahaan lebih berhati-hati dalam melakukan pelaporan keuangannya. Perusahaan diharapkan akan selalu berusaha menjaga stabilitas kinerja keuangan mereka. Pelaporan kondisi keuangan yang baik ini tentu tidak serta merta dapat dilakukan tanpa melalui kinerja yang baik dari semua lini perusahaan.

Berdasarkan uraian di atas, maka hipotesis dalam penelitian ini di rumuskan sebagai berikut :

$\mathrm{H}_{4}$ : Ukuran perusahaan berpengaruh positif terhadap kinerja perusahaan.

\section{METODE PENELITIAN}

Penelitian ini dilakukan pada perusahaaan yang terdaftar di Bursa Efek Indonesia (BEI) yang di peroleh dari situs www.idx.co.id. Sumber data penelitian ini adalah data yang diperoleh secara historis dari laporan keuangan auditan dan laporan tahunan (annual report) yang dipublikasikan oleh perusahaan yang telah terdaftar di Bursa Efek Indonesia periode tahun 2013-2017.

Menurut Rodiyah (2018) mengemukakan bahwa pengukuran ROE dapat dihitung dengan rumus sebagai berikut:

$$
\text { Return On Equity }(R O E)=\frac{\text { Earning After Tax }}{\text { Total Equity }}
$$

GCG di proksikan dengan Skor CGPI yang dikeluarkan oleh IICG dan dipublikasikan oleh Majalah SWA. Sistematika penilaian CGPI terdiri dari empat tahapan, yaitu self-assessment, sistem dokumentasi, penilaian makalah, dan observasi.

Menurut Aprianingsih (2016) mengemukakan bahwa kepemilikan manajerial diukur dengan jumlah seluruh saham yang dimiliki oleh manajemen terhdap seluruh saham yang beredar dalam suatu perusahaan. Berikut rumus kepemilikan mnajerial:

$$
\text { Kepemilikan Manajerial }=\frac{\text { jumlah saham yang dimiliki manajemen }}{\text { Jumlah saham yang beredar }}
$$

Menurut Aprianingsih (2016) kepemilikan Institusional diukur dengan jumlah seluruh saham yang dimiliki oleh lembaga institusional terhadap jumlah saham yang beredar di dalam suatu perusahaan. Berikut rumus kepemilikan manajerial

Kepemilikan Institusional $=\frac{\text { jumlah saham yang dimiliki institusi }}{\text { Jumlah saham yang beredar }}$

Menurut Astika Sari (2014) mengemukakan bahwa rumus ukuran perusahaan sebagai berikut :

Ukuran Perusahaan $=$ Ln Total Assets

Populasi yang digunakan dalam penelitian ini perusahaan yang telah terdaftar di Bursa Efek Indonesia periode tahun 2013-2017. Jumlah populasi dalam penelitian ini sebanyak 603 perusahaan.Teknik pengambilan sampel pada penelitian ini dilakukan dengan menggunakan teknik purposive sampling, yang berarti pemilihan sampel berdasarkan kriteria tertentu. 
Tabel 1. Kriteria Pemilihan Sampel

\begin{tabular}{lll}
\hline No & Kriteria & Jumlah \\
\hline 1 & Perusahaan yang terdaftar di BEI tahun 2013-2017 & 603 \\
2 & Perusahaan yang tidak mengikuti pemeringkatan CGPI periode 2013- & $(592)$ \\
$\quad 2017$ & 11 \\
Jumlah perusahan yang terpilih dijadikan sampel & 55 \\
Jumlah pengamatan penelitian selama lima tahun penelitian & 55 \\
\hline
\end{tabular}

Sumber: Data Penelitian, 2019

Teknik analisis data yang digunakan dalam penelitian ini adalah analisis statistik yang menggunakan regresi linier berganda dan menggunakan software SPSS. Teknik analisis regresi berganda merupakan analisis yang digunakan untuk mengukur kekuatan dua variabel atau lebih dan juga menunjukkan arah hubungan antara variabel dependen dengan variabel independen. Model regresi yang digunakan adalah sebagai berikut:

$\mathrm{Y}=\mathrm{a}+\mathrm{b} 1 \mathrm{x} 1+\mathrm{b} 2 \mathrm{x} 2+\mathrm{b} 3 \mathrm{x} 3+\mathrm{b} 4 \mathrm{x} 4+\mathrm{e}$

Keterangan:

$$
\begin{aligned}
& \mathrm{Y}=\text { Kinerja Perusahaan } \\
& X_{1}=\text { Good Corporate Governance } \\
& \mathrm{X}_{2} \quad=\text { Kepemilikan Manajerial } \\
& \mathrm{X}_{3}=\text { Kepemilikan Institusional } \\
& \mathrm{X}_{4} \quad=\text { Ukuran Perusahaan } \\
& \text { a } \quad=\text { Konstanta } \\
& \mathrm{b}_{1}, \mathrm{~b}_{2}, \mathrm{~b}_{3}, \mathrm{~b}_{4}, \mathrm{~b}_{5}, \mathrm{~b}_{6}=\text { Koefisien regresi dari variabel independence } \\
& \text { e }=\text { error }
\end{aligned}
$$

\section{HASIL DAN PEMBAHASAN}

Analisis statistik deskriptif disajikan untuk memberikan informasi umum tentang karakteristik sampel yang berupa nilai tertinggi, nilai terendah, rata-rata, dan deviasi standar. Hasil statistik deskriptif dapat dilihat pada Tabel 4.3 sebagai berikut:

Tabel 2. Hasil Statistik Deskriptif

\begin{tabular}{cccccc}
\hline Variabel & $\mathrm{N}$ & Minimum & Maximum & Mean & Std. Deviation \\
\hline CGPI & 55 & 80,10 & 93,86 & 87,4042 & 3,04586 \\
MNJR & 55 & 0,00 & 0,02 & 0,0022 & 0,00570 \\
INST & 55 & 0,18 & 0,95 & 0,4862 & 0,22528 \\
SIZE & 55 & 11,12 & 14,88 & 13,1719 & 1,19522 \\
ROE & 55 & 0,00 & 0,33 & 0,1528 & 0,07789 \\
\hline
\end{tabular}

Sumber: Data Penelitian, 2019

Variabel kinerja perusahaan dalam penelitian ini diukur menggunakan rasio Return On Equity (ROE) yang dihitung dengan cara membagi laba sesudah pajak dengan total ekuitas. Berdasarkan Tabel 2, nilai rata-rata ROE sebesar 0,1528 mendekati nilai maksimal sebesar 0,33, artinya rata-rata perusahaan memiliki kinerja yang baik dan mampu meningkatkan kinerja perusahaan. Nilai standar deviasi atas kinerja perusahaan sebesar 0,07789 nilai ini lebih rendah dibandingkan nilai rata-rata. Hal ini menunjukkan bahwa sebaran data terkait 
kinerja perusahaan sudah merata atau perbedaan data satu dengan data yang lainnya tidak tergolong tinggi. Nilai minimum sebesar 0,0035 dimiliki oleh ANTM pada tahun 2016, kinerja perusahaan bernilai positif dapat mengindikasikan bahwa kualitas dan kinerja fundamental perusahaan tersebutmeningkat, sementara nilai maksimum sebesar 0,3295 dimiliki oleh PTBA pada tahun 2017, dapat dikatakan bahwa perusahaan tersebut sudah mampu meningkatkan kualitas dan kinerja fundamentalnya.

Variabel GCG dalam penelitian ini diukur menggunakan skor CGPI. Berdasarkan Tabel 2, nilai rata-rata CGPI sebesar 87,4042 mendekati nilai maksimal sebesar 93,86. Artinya, adanya kecenderungan rata-rata perusahaan sudah baik dalam menerapkan GCG. Nilai deviasi standar GCG sebesar 3,04586 lebih rendah dibandingkan dengan nilai rata rata, artinya sebaran data GCG sudah merata atau perbedaan data satu dengan data yang lainnya tidak tergolong tinggi. Nilai CGPI terendah sebesar 80,10 dimiliki oleh TINS pada tahun 2013, menunjukkan masih terdapat perusahaan yang belum menerapkan GCG dengan baik. Nilai tertinggi CGPI sebesar 93,86 dimiliki oleh BMRI pada tahun 2017, yang menunjukkan bahwa perusahaan sudah menerapkan GCG dengan maksimal. Variabel kepemilikan manajerial dalam penelitian ini diukur dengan jumlah seluruh saham yang dimiliki oleh manajemen terhdap seluruh saham yang beredar dalam suatu perusahaan. Berdasarkan Tabel 2 nilai rata-rata kepemilikan manajerial sebesar 0,0022 mendekati nilai minimum sebesar 0,02. Artinya, ada kecendrungan rata-rata perusahaan kurang menerapkan kepemilikan majaerial dengan baik. Nilai standar deviasi kepemilikan manajerial sebesar 0,00570 lebih tinggi daripada nilai rata-ratanya, artinya sebaran data kepemilikan manajerial belum merata atau terdapat perbedaan data satu dengan data yang lainnya yang tergolong tinggi. Nilai kepemilikan manajerial terendah sebesar 0,0000 yang masih dimiliki oleh beberapa perusahaan, hal ini menunjukkan masih terdapat perusahaan yang belum menerapkan kepemilikan manajerial dengan maksmimal. Nilai tertinggi kepemilikan manajerial sebesar 0,0199 dimiliki BBCA pada tahun 2013 hingga 2017, hal tersebut menunjukkan bahwa perusahaan BBCA sudah menerapkan kepemilikan manajerial dengan maksimal.

Variabel kepemilikan institusional dalam penelitian ini diukur dengan jumlah seluruh saham yang dimiliki oleh lembaga institusional terhadap jumlah saham yang beredar di dalam suatu perusahaan. Berdasarkan Tabel 2 nilai ratarata kepemilikan institusional sebesar 0,4862 mendekati nilai maksimum sebesar 0,95 . Artinya, ada kecendrungan rata-rata perusahaan sudah menerapkan kepemilikan institusional dengan baik. Nilai standar deviasi kepemilikan institusional sebesar 0,22528 lebih rendah daripada nilai rata-ratanya, artinya sebaran data kepemilikan institusional sudah merata atau tidak ada perbedaan data satu dengan data yang lainnya yang tergolong tinggi. Nilai kepemilikan institusional terendah sebesar 0,17888 yang dimiliki oleh TINS pada tahun 2016, hal ini menunjukkan perusahaan yang belum menerapkan kepemilikan institusional dengan maksmimal. Nilai tertinggi kepemilikan institusional sebesar 0,95 dimiliki BBCA pada tahun 2013 hingga 2017, hal tersebut menunjukkan bahwa perusahaan BBCA sudah menerapkan kepemilikan institusional dengan maksimal. 
Variabel ukuran perusahaan dalam penelitian ini diukur dengan menggunakan total aset, karena total aset lebih stabil dan representatif dalam menunjukkan ukuran perusahaan dibandingkan dengan kapitalisasi pasar dan penjualan karena sangat dipengaruhi oleh supply dan demand. Berdasarkan Tabel 4.3 nilai rata-rata ukuran perusahaan sebesar 13,1719 mendekati nilai maksimum sebesar 13,1719. Artinya, ada kecendrungan rata-rata perusahaan sudah memiliki ukuran perusahaan dengan baik. Nilai standar deviasi ukuran perusahaan sebesar 1,19522 lebih rendah daripada nilai rata-ratanya, artinya sebaran data ukuran perusahaan sudah merata atau tidak ada perbedaan data satu dengan data yang lainnya yang tergolong tinggi. Nilai ukuran perusahaan terendah sebesar 0,0035 yang dimiliki oleh ANTM pada tahun 2016, hal ini menunjukkan perusahaan belum menerapkan ukuran perusahaan dengan maksmimal. Nilai tertinggi ukuran perusahaan sebesar 0,3295 dimiliki PTBA pada tahun 2017, hal tersebut menunjukkan bahwa perusahaan PTBA sudah menerapkan ukuran perusahaan dengan maksimal.

Hipotesis penelitian diuji dengan menggunakan analisis regresi linear berganda. Analisis ini digunakan untuk mengetahui besarnya pengaruh penerapan GCG yang diproksikan dengan CGPI $\left(\mathrm{X}_{1}\right)$, kepemilikan manajerial yang diproksikan dengan MNJR $\left(\mathrm{X}_{2}\right)$, kepemilikan institusional yang diproksikan dengan INST $\left(X_{3}\right)$, dan ukuran perusahaan yang di proksikan dengan Ln_Total Aset $\left(\mathrm{X}_{4}\right)$ pada Kinerja perusahaan yang diproksikan dengan ROE (Y). Hasil olahan data dengan SPSS menggunakan model analisis regresi linear berganda dapat dilihat pada Tabel 3 sebagai berikut:

Tabel 3. Hasil Analisis Regresi Linear Berganda

\begin{tabular}{lllllll}
\hline Model & \multicolumn{5}{c}{$\begin{array}{l}\text { Standardized } \\
\text { Coefficients }\end{array}$} & \\
\cline { 3 - 5 } & & \multicolumn{3}{c}{ Unstandardized Coefficients } & \multicolumn{1}{c}{ Sig. } \\
\cline { 3 - 5 } & (Constant) & 0,119 & 0,133 & & 0,894 & 0,376 \\
& CGPI & 0,405 & 0,158 & 0,401 & 2,562 & 0,013 \\
& MNJR & 0,604 & 0,280 & 0,430 & 2,154 & 0,036 \\
& INST & 0,172 & 0,243 & 0,157 & 0,707 & 0,483 \\
& SIZE & 0,410 & 0,193 & 0,333 & 2,126 & 0,038 \\
\hline
\end{tabular}

Sumber: Data Penelitian, 2019

Dari hasil analisis regresi linear berganda pada Tabel 3 dapat dibuat persamaan sebagai berikut:

$$
Y=0,119+0,405 X 1+0,604 X 2+0,172 X 3+0,410 X 4
$$

Nilai konstanta $(\alpha)$ sebesar 0,119 berarti apabila GCG $\left(X_{1}\right)$, kepemilikan manajerial $\left(X_{2}\right)$, kepemilikan institusional $\left(X_{3}\right)$ dan ukuran perusahaan $\left(X_{4}\right)$ bernilai 0, maka kinerja perusahaan adalah sebesar 0,119 satuan.Nilai koefisien regresi CGG $\left(\beta_{1}\right)$ sebesar 0,405 berarti apabila GCG meningkat sebesar 1 satuan dengan anggapan variabel lainnya konstan, maka kinerja perusahaan akan meningkat sebesar 0,405 satuan.Nilai koefisien regresi kepemilikan manajerial $\left(\beta_{2}\right)$ sebesar 0,604 berarti apabila kepemilikan manajerial meningkat sebesar 1 satuan dengan anggapan variabel lainnya konstan, maka kinerja perusahaan akan meningkat sebesar 0,604 satuan.Nilai koefisien regresi kepemilikan institusional $\left(\beta_{3}\right)$ sebesar 0,172 berarti apabila kepemilikan institusional meningkat sebesar 1 satuan dengan anggapan variabel lainnya konstan, maka 
kinerja perusahaan akan meningkat sebesar 0,172 satuan.Nilai koefisien regresi ukuran perusahaan $\left(\beta_{4}\right)$ sebesar 0,410 berarti apabila ukuran perusahaan meningkat sebesar 1 satuan dengan anggapan variabel lainnya konstan, maka kinerja perusahaan akan meningkat sebesar 0,410 satuan.

Uji koefisien determinasi pada intinya bertujuan untuk mengetahui dan mengukur kemampuan model dalam menerangkan variasi variabel independen. Nilai koefisien determinisi dapat dilihat pada adjusted $\mathrm{R}^{2}$ dalam model regresi. Peneliti menggunakan nilai adjusted $\mathrm{R}^{2}$ pada saat mengevaluasi yang mana model regresi terbaik, karena nilai adjusted $\mathrm{R}^{2}$ dapat naik atau turun apabila satu variabel independen ditambahkan ke dalam model. Hasil uji koefisien determinasi dapat dilihat pada Tabel 4 .

Tabel 4. Hasil Uji Koefisien Determinasi

\begin{tabular}{ccccc}
\hline Model & $R$ & $R$ Square & Adjusted $R$ Square & $\begin{array}{c}\text { Std. Error of the } \\
\text { Estimate }\end{array}$ \\
\hline 1 & $0,430^{\text {a }}$ & 0,185 & 0,120 & 0,93826395 \\
\hline
\end{tabular}

Sumber: Data Penelitian, 2019

Hasil uji memberikan hasil dimana diperoleh besarnya adjusted $\mathrm{R}^{2}$ (koefisien determinasi yang telah disesuaikan) adalah 0,120. Ini berarti variasi kinerja perusahaan dapat dipengaruhi secara signifikan oleh variabel GCG $\left(X_{1}\right)$, kepemilikan manajerial $\left(X_{2}\right)$, kepemilikan institusional $\left(X_{3}\right)$ dan ukuran perusahaan $\left(\mathrm{X}_{4}\right)$ sebesar 12 persen sedangkan sisanya sebesar 88 persen dijelaskan oleh faktor-faktor lain yang tidak dijelaskan dalam model penelitian

Uji kelayakan model regresi bertujuan untuk mengetahui apakah semua variabel bebas yang diidentifikasi (GCG $\left(X_{1}\right)$, kepemilikan manajerial $\left(X_{2}\right)$, kepemilikan institusional $\left(X_{3}\right)$ dan ukuran perusahaan $\left(X_{4}\right)$ ) tepat digunakan memprediksi Kinerja perusahaan. Uji ini sering juga disebut dengan uji F. Hasil uji $\mathrm{F}$ dapat dilihat pada Tabel 5.

Tabel 5. Hasil Uji F

\begin{tabular}{ccccccc}
\hline & Model & Sum of Squares & $d f$ & Mean Square & $F$ & Sig. \\
\hline 1 & Regression & 9.983 & 4 & 2,496 & 2,835 & $0,034^{\mathrm{a}}$ \\
& Residual & 44.017 & 50 & 0,880 & & \\
& Total & 54.000 & 54 & & & \\
\hline
\end{tabular}

Sumber: Data Penelitian, 2019

Hasil uji F (Ftest) pada Tabel 5 menunjukkan bahwa nilai $\mathrm{F}$ hitung sebesar 2,835dengan nilai signifikansi $\mathrm{P}$ value 0,034 yang lebih kecil dari $\mathrm{a}=0,05$, ini berarti model yang digunakan pada penelitian ini adalah layak. Hasil ini memberikan makna bahwa seluruh variabel independen yaitu GCG ( $\left.X_{1}\right)$, kepemilikan manajerial $\left(X_{2}\right)$, kepemilikan institusional $\left(X_{3}\right)$ dan ukuran perusahaan $\left(\mathrm{X}_{4}\right)$ tepat memprediksi atau menjelaskan fenomena Kinerja perusahaan. Dengan kata lain, GCG $\left(X_{1}\right)$, kepemilikan manajerial $\left(X_{2}\right)$, kepemilikan institusional $\left(X_{3}\right)$ dan ukuran perusahaan $\left(X_{4}\right)$ secara simultan berpengaruh signifikan pada kinerja perusahaan.

Berdasarkan hasil analisis pengaruh Penerapan GCG terhadap Kinerja perusahaan diperoleh nilai signifikansi sebesar 0,013 dengan nilai koefisien regresi positif sebesar 0,405. Nilai signifikansi 0,013 < 0,050 mengindikasikan bahwa $\mathrm{H}_{1}$ diterima. Hasil ini mempunyai arti bahwa Penerapan GCG berpengaruh positif dan signifikan terhadap kinerja perusahaan. 
Berdasarkan hasil analisis pengaruh kepemilikan manajerial terhadap Kinerja perusahaan diperoleh nilai signifikansi sebesar 0,036 dengan nilai koefisien regresi positif sebesar 0,604. Nilai signifikansi 0,036 $<0,050$ mengindikasikan bahwa $\mathrm{H}_{2}$ diterima. Hasil ini mempunyai arti bahwa kepemilikan manajerial berpengaruh positif dan signifikan terhadap kinerja perusahaan.

Berdasarkan hasil analisis pengaruh kepemilikan Institusional terhadap Kinerja perusahaan diperoleh nilai signifikansi sebesar 0,483 dengan nilai koefisien regresi positif sebesar 0,172. Nilai signifikansi 0,483 $>0,050$ mengindikasikan bahwa $\mathrm{H}_{3}$ ditolak. Hasil ini mempunyai arti bahwa kepemilikan institusional tidak berpengaruh signifikan terhadap kinerja perusahaan.

Berdasarkan hasil analisis pengaruh ukuran perusahaan terhadap Kinerja perusahaan diperoleh nilai signifikansi sebesar 0,038 dengan nilai koefisien regresi positif sebesar 0,410. Nilai signifikansi 0,038 < 0,050 mengindikasikan bahwa $\mathrm{H}_{4}$ diterima. Hasil ini mempunyai arti bahwa ukuran perusahaan berpengaruh positif terhadap Kinerja perusahaan.

Hasil penelitian ini menunjukkan GCG berpengaruh positif dan signifikan terhadap Kinerja perusahaan. Karena, besar kecilnya nilai CGPI yang diperoleh perusahaan mampu memengaruhi kenaikan kinerja perusahaan yang diproksikan dengan Return On Equity. Hal ini dikarenakan, CGPI dinilai berdasarkan komitmen, transparansi, akuntabilitas, independensi, keadilan, dan kompetensi perusahaan dalam mengelola perusahaannya. Semakin besar nilai CGPI yang diperoleh, mengindikasikan semakin baik pengelolaan perusahaan untuk mencegah adanya tindakan oportunistik manajemen yang dapat merugikan perusahaan. CGPI menjadi salah satu pertimbangan investor untuk menilai kinerja perusahaan, karena perusahaan yang dikelola lebih baik dapat menghasilkan keuntungan yang tinggi sehingga dividen yang dibagikan akan tinggi pula. Untuk itu, investor bersedia membayar premium yang lebih besar pada perusahaan yang memberikan transparansi atas penerapan GCG dalam laporan tahunan mereka.

Hasil penelitian ini juga mampu mendukung teori agensi yaitu perbedaan kepentingan antara prinsipal dan agen dapat diminimalisir dengan adanya pengawasan yang optimal dari kedua belah pihak. Mekanisme corporate governance dapat menjadi solusi untuk konflik ini karena didalammnya terdapat penetapan distribusi hak dan kewajiban di antara berbagai pihak yang terlibat, sehingga implementasinya yang baik mampu menyeimbangkan berbagai kepentingan dan memengaruhi kenaikan kinerja perusahaan secara signifikan (Wulansari, 2017).

Temuan ini sejalan dengan penelitian yang dilakukan oleh Andriana (2017), Suntraruk (2013), Veno (2015), dan Meidona, (2018) yang menemukan bahwa GCG berpengaruh positif terhadap kinerja. Dengan adanya Prinsip GCG dalam suatu perusahaaan diharapkan perusahaan akan memiliki nilai tambah bagi para investor, pemangku kepentingan serta mendorong Kinerja agar sesuai dengan prinsip GCG.

Hasil penelitian ini menunjukkan bahwa kepemilikan manajerial berpengaruh positif dan signifikan terhadap kinerja perusahaan. Hal tersebut 
dikarenakan kepentingan para manajer yang juga memiliki perusahaan. Kinerja manjerial merupakan suatu persentase suara yang berkaitan dengan saham dan option yang dimiliki oleh manajer dan direksi perusahaan.Adanya kepemilikan manajerial dalam suatu perusahaan maka manajer akan terpacu untuk memajukan perusahaanya agar dapat menguntungkan bagi dirinya sendiri dan pemegang saham yang menanamkan modalnya dalam perusahaan.

Temuan ini sejalan dengan penelitian yang dilakukan oleh (Maulana, 2016)menyatakan bahwa untuk mengurangi konflik kepentingan antara agent dan principal dapat dilakukan dengan meningkatkan kepemilikan manjerial dalam suatu perusahaan. Hasil penelitian ini juga mendukung temuan penelitian Aprianingsih (2016), Anita 2016) dan O'Callaghan (2018) yang menyatakan bahwa Semakin meningkat proporsi kepemilikan saham manajerial maka manjemen akan cenderung berusaha lebih giat untuk kepentingan saham yang tidak lain adalah dirinya sendiri. Adanya peningkatan kepemilikan manajerial dalam perusahaan akan menyelaraskan kepentingan manajer dengan pemegang saham, sehingga manajer akan merasakan secara langsung manfaat dari keputusan yang diambil dan juga ikut menanggung kerugian sebagai sebuah konsekuensi dari kesalahan dalam pengambilan keputusan, sehingga kinerja perusahaan yang dihasilkan akan semakin meningkat.

Hasil penelitian ini menunjukan kepemilikan manajerial tidak berpengaruh signifikan terhadap kinerja perusahaan. Hal tersebut dikarenakan pemilik yang mayoritas institusi ikut dalam pengendalian perusahaan sehingga cenderung bertindak untuk kepentingan mereka sendiri meskipun dengan mengorbankan kepentingan pemilik minoritas. Dengan adanya kecenderungan tersebut membuat terjadinya ketidakseimbangan dalam penentuan arah kebijakan perusahaan yang pada akhirnya hanya akan menguntungkan pemegang saham mayoritas.

Hasil penelitian ini sejalan dengan temuan penelitian Dewi (2016), Sintyawati (2017) yang memperoleh hasil bahwa tidak terdapat pengaruh yang signifikan antara kepemilikan institusional terhadap kinerja perusahaan. Namun hasil ini tidak mendukung temuan Natali (2017), Apriada (2016) , Purwati dkk., (2018) bahwa semakin besar kepemilikan oleh institusi keuangan maka semakin besar pula kekuatan suara dan dorongan untuk mengoptimalkan nilai perusahaan. Selain itu, semakin tinggi kepemilikan institusional maka akan mengurangi perilaku opportunisme manajer yang dapat mengurangi agency cost yang diharapkan akan meningkatkan nilai perusahaan. Hal tersebut dapat didasarkan pada logika bahwa semakin besar kepemilikan oleh institusi dalam perusahaan, maka akan semakin besar kekuatan suara dan dorongan institusi untuk mengawasi manajemen, sehingga diharapkan akan memberikan dorongan yang lebih besar untuk mengoptimalkan nilai perusahaan serta adanya peningkatan kinerja perusahaan. Tingginya kepemilikan oleh sebuah institusi akan meningkatkan pengawasan terhadap perusahaan yang dapat meminimalisir masalah keagenan.

Hasil penelitian ini menunjukkan ukuran perusahaan berpengaruh positif terhadap Kinerja perusahaan. Hal ini disebabkanperusahaan dengan aset besar biasanya akan mendapatkan perhatian lebih dari masyarakat. Hal ini akan menyebabkan perusahaan lebih berhati-hati dalam melakukan pelaporan 
keuangannya. Perusahaan diharapkan akan selalu berusaha menjaga stabilitas kinerja keuangan mereka. Pelaporan kondisi keuangan yang baik ini tentu tidak serta merta dapat dilakukan tanpa melalui kinerja yang baik dari semua lini perusahaan.

Perusahaan besar pada dasarnya memiliki kekuatan finansial yang lebih besar dalam menunjang kinerja, tetapi disisi lain, perusahaan dihadapkan pada masalah keagenan yang lebih besar. Hasil penelitian ini juga mendukung temuan Hantono (2016), Ulfa (2016), Yuli (2017) yang menemukan bukti bahwa ukuran perusahaan berpengaruh positif signifikan terhadap kinerja perusahaan. Hal ini menunjukkan bahwa ukuran perusahaan merupakan hal yang penting dalam proses pelaporan keuangan. Apabila suatu perusahaan memiliki total aset yang besar bisa disimpulkan bahwa perusahaan tersebut adalah perusahaan besar. Perusahaan besar biasanya dipandang sebagai perusahaan yang relatif stabil dan mampu menghasilkan laba yang cukup tinggi. Pihak luar maupun investor akan melihat perusahaan besar ini sebagai perusahaan yang baik untuk menanamkan dananya sehingga memiliki nama atau reputasi yang baik di mata pihak eksternal. reputasi yang baik akan membuat manajer semakin berhati-hati dalam melakukan pengelolaan perusahaan. Manipulasi dan tindak kecurangan dalam perusahaan pun akan berkurang.

\section{SIMPULAN}

Hasil penelitian menunjukkan implementasi GCG berpengaruh positif dan signifikan terhadap kinerja perusahaan. Hal ini berarti perusahaan yang terdaftar di Bursa Efek Indonesia dan mengikuti survei yang dilakukan oleh IICG telah menerapkan corporate governance dengan baik, maka kinerja perusahaan akan meningkat. Semakin tinggi penerapan corporate governance yang diukur dengan corporate governance perception indeks semakin tinggi pula tingkat ketaatan perusahaan dan menghasilkan kinerja perusahaan yang baik.

Hasil penelitian menunjukkan bahwa kepemilikan manajerial berpengaruh positif dan signifikan terhhadap Kinerja perusahaan. Dengan adanya kepemilikan manajerial dalam suatu perusahaan akan membuat manajer terpacu untuk memajukan perusahaanya agar dapat menguntungkan bagi dirinya sendiri dan pemegang saham yang menanamkan modalnya dalam perusahaan.

Hasil pengujian menunjukkan kepemilikan institusional tidak berpengaruh signifikan terhadap Kinerja perusahaan. Hal ini terjadi akibat adanya pemilik saham mayoritas institusi yang ikut dalam pengendalian perusahaan sehingga cenderung bertindak untuk kepentingan mereka sendiri meskipun dengan mengorbankan kepentingan pemilik minoritas.

Hasil Pengujian menunjukkan bahwa ukuran perusahaan berpengaruh positif terhadap Kinerja perusahaan. Perusahaan dengan aset besar biasanya akan mendapatkan perhatian lebih dari masyarakat. Hal ini akan menyebabkan perusahaan lebih berhati-hati dalam melakukan pelaporan keuangannya. Perusahaan diharapkan akan selalu berusaha menjaga stabilitas kinerja keuangan mereka agar mendapat kepercayaan dari investor atau masyarakat. 


\section{REFERENSI}

Adebayo, M., Ibrahim, A. O. B., Yusuf, B., \& Omah, I. (2014). Good Corporate Governance and Organisational Performance: An Empirical Analysis Abstract. International Journal of Humanities and Social Science, 4 (7), 170-178.

Aggrawal, P. (2013). Impact of Corporate Governance on Corporate Financial Performance. Journal of Business and Management, 13(3), 1-5.

Andriana, A. (2017). The effect of good corporate governance and environmental performance on financial performance of the proper listed company on indonesia stock exchange. Journal Binus, 8, 1-8.

Anita, A. (2016). Pengaruh kepemilikan manajerial dan kebijkan dividen terhadap nilai perusahaan. Journal Management Analysis, 5 (1), 17-23.

Apriada, K. (2016). Kepemilikan manajeral: kebijakan hutang, kinerja dan nilai perusahaan. Jurnal Ekonomi Akuntansi, 201-218.

Aprianingsih, A. (2016). Pengaruh penenrapan good corporate governance, struktur kepemilikan, dan ukuran perusahaan terhadap kinerja keuangan perbankan. Jurnal Profita, 11 (2), 1-16.

Arora, A., \& Sharma, C. (2016). Corporate governance and firm performance in developing countries: evidence from India. Corporate Governance: The International Journal of Business in Society, 16(2), 420-436.

Astika Sari, D. (2014). Pengaruh good corporate governance terhadap manajemen laba. Jurnal Akuntansi, 1-17. Retrieved from

Ayu. (2014). Pengaruh good corporate governance dan ukuran perusahaan terhadap kinerja perusahaan. Jurnal Manajemen Dan Bisnis, 1-16.

Bringham, \& Huston. (2013). Dasar-Dasar Manajemen Keuangan. (S. Empat, Ed.) (11th ed.). Jakarta: Salemba Empat.

Claudia, A. (2017). Pengaruh keberadaan wanita dalam manajemen puncak dan kepemilikan manajerial terhadap kinerja keuangan perbankan. Jurnal EMBA, 5 (2), 821-828.

Dewi Widowati, S. (2016). Pengaruh sturktur kepemilikam dan struktur modal terhadap nilai perusahaan. Jurnal, 2-14.

Hantono. (2016a). Pengaruh ukuran perusahaan, total hutang, current ratio, terhadap kinerja keuangan dan harga saham sebagai variabel moderating. Jurnal Wira Ekonomi Mikroskil, 1 (1), 35-44.

Hantono. (2016b). Pengaruh Ukuran Perusahaan, Total Hutang, Current Ratio, Terhadap Kinerja Keuangan dan Harga Sebagai Variabel Moderating. Jurnal Wira Ekonomi Mikroskil, 6 (2), 35-44.

Jacobo-Hernandez, C. A., \& Sergio Ochoa Jiménez. (2017). Corporate Governance: International Context and Trends from 2005 to 2015. Reseacrh Gate, 12 (3), 158-169.

Krenz, A. (2016). Firm structure and the location decision of German manufacturing firms: Evidence from official firm-level data. Econstor, 1-13.

Maulana, A. (2016). Pengaruh kinerja keuangan terhadap nilai perusahaan dengan mekanisme good corporate governance sebagai variabel moderasi. JOM Fekom, 3(1), 993-1005.

Meidona, S. (2018). Pengaruh corporate governance dan kualitas audit terhadap kinerja keuangan pada perusahaan LQ45. Jurnal Indovisi, 1, 67-82.

Michael C, J., \& Meckling, W. H. (1976). Theory of the Firm: Managerial Behavior, 
Agency Costs and Ownership Structure. Journal of Financial Economics, 3, 305-360.

Michelbelger, K. J. (2017). Impact of corporate governance on firm performance and total shareholder return of german listed company. University of Latvia.

Mittal Shrivastav, S. (2015). A review on corporate governance in india: impact on firm performance. International Journal of Business and Administration $R$, $1(11), 170-174$.

Natali Tanzil, S. (2017). Pengaruh struktur kepemilikan keluarga terhadap kinerja perusahaan pada sektor perdagangan, jasa, dan investasi. Jurnal Bisnis Akuntansi, 5, 241-252.

Nurdin. (2016). Analisis pengaruh tata kelola perusahaan yang baik terhadap keunggulan bersaing pada bank perkreditan rakyat. Jurnal Manajemen Dan Bisnis Performa, 12, 122-135.

Nurdiniah1, D., \& Endra, P. (2017). Effect of good corporate governance, KAP Reputation, Its Size and leverage on integrity of financial statements. International Journal of Economics and Financial, 7(4), 174-181.

O'Callaghan, S. (2018). The impact of corporate governance and financial leverage on the value of american firms. Journal Emerald Publishing Limited, $19(4), 1-15$.

Omoregie, O. K., Olofin, S. A., \& Ikpesu, F. (2019). Capital structure and the profitability-liquidity trade-off. International Journal of Economics and Financial Issues, 9(3), 105-111.

Purwati, D., Noviansyah, R., \& Munir, M. (2018). Pengaruh struktur kepemilikan terhadap kinerja perusahaan. Jurnal Progress Conference, 1 (1), 724-720.

Rejeb, W. Ben, \& Frioui, M. (2014). No Title. The Impact of Good Corporate Governance Practices on Stakeholder's Satisfaction in Tunisian Listed Companies, 4 (2), 187-199.

Restu, F. (2018). Struktur kepemilikan dan nilai perusahaan. Research Gate, 1 (2).

Reza, A. (2014). Pengaruh kepemilikan manajerial dan kepemilikan institusional terhadap kinerja keuangan pada perusahaan manufaktur yang terdaftar di BEI. Jurnal Manajemen Dan Bisnis, 1-12.

Rizal Putri, V., \& Putra, B. I. (2016). Pengaruh Leverage, Profitabilitas, Ukuran Perusahaan Dan Proporsi Kepemilikan Institusional Terhadap Tax Avoidance, 1-11. Retrieved from $\mathrm{f}$

Rodiyah Aisyatur, W. (2018). Pengaruh return on investmen (ROI), return on equity (ROE), earning per share (EPS) dan economic value added (EVA) terhadap harga saham. Jurnal Administrasi Bisnis, 59, 125-133.

Rubianti, N. (2013). Analisa rasio keuangan untuk menilai kinerja perusahaan. Jurnal Universitas Maritim Raja Ali Haji, 1-17.

Sintyawati, N. L. A. (2017). Pengaruh Kepemilikan Manajerial, Kepemilkan Institusional Institusional dan Leverage Terhadap Biaya Keagenan Pada Perusahaan Manufaktur. E-Jurnal Manajemen Unud, 7(2), 992-1017.

Suntraruk, P. (2013). an empricial analysis on the association between corporate governance rating and firms' characteristics: evidence from MAI Thailand. Journal of Academic Research in Business and Social Sciences, 3, 732-744.

Tytus Harimukti, W. (2016). Pengaruh dewan komisaris, Kepemilikan institusional, dan leverage terhadap kinerja. Jurnal, 1-16. 
Ulfa Syahida, L. (2016). Pengaruh diversivikasi moderat, ukuran perusahaan dan struktur modal terhadap kinerja perusahaan. Jurnal Prosiding Akuntansi, 2, 159-165.

Veno, A. (2015). Pengaruh good corporate governance terhadap kinerja perusahaan pada perusahaan manufaktur go public. Jurnal Manajemen Dan Bisnis, 19, 95-112.

Wandroski Peris, R., Contani, E., Ferreira Savoia, J. R., \& Reed Bergmann, D. (2017). Does better corporate governance increase operational performance? Corporate Governance: The International Journal of Business in Society, 17(3), 524-537.

Wulansari, R. (2017). Pengaruh corporate social responsibility dan good corporate governance terhadap nilai perusahaan. Jurnal Ilmu Dan Riset Akuntansi, 6(8), 1-19.

Yuli Sawitri, N. M. (2017). Pengaruh kinerja keuangan, ukuran perusahaan dan struktur kepemilikan terhadap profitabilitas. Jurnal, 7, 1-12.

Yus, E. (2017). Pengruh ukuran perusahaan, struktur kepemilikan manajerial dan manajemen laba terhadap kinerja perusahaan property dan real estate. Jurnal Riset Akuntansi, 1 (1), 1-7.

Zarkasyi, A. F., Siahaan, D., \& Iswati, S. (2019). Social enterprise: the alternatives financial support for educational institusion. International Journal of Economics and Financial, 9(3), 1-11. 